\title{
Ernst Julius Öpik, an undervalued Estonian precursor of the Alvarez impact catastrophism
}

Grzegorz Racki

Acta Palaeontologica Polonica 57 (4), 2012: 680-680 doi: http://dx.doi.org/10.4202/app.2012.1001

Grzegorz Racki [grzegorz.racki@us.edu.pl], Department of Earth Sciences, Silesian University, ul. Będzińska 60, PL-41-200 Sosnowiec, Poland.

This is an open-access article distributed under the terms of the Creative Commons Attribution License (for details please see creativecommons.org), which permits unrestricted use, distribution, and reproduction in any medium, provided the original author and source are credited.

For Full text $(60.8 \mathrm{kB})$ 